\title{
IMPACT OF CLIMATE CHANGE ON PRODUCTION AND PRODUCTIVITY: A CASE STUDY OF MAIZE RESEARCH AND DEVELOPMENT IN NEPAL
}

\author{
Janak Lal Nayava, $\mathrm{PhD}^{1}$ and Dil Bahadur Gurung, $\mathrm{PhD}^{2}$
}

\section{ABSTRACT}

The relation between climate and maize production in Nepal was studied for the period 1970/71-2007/08. Due to the topographical differences within north-south span of the country, Nepal has wide variety of climatic condition. About 70 to $90 \%$ of the rainfall occurs during summer monsoon (June to September) and the rest of the months are almost dry. Maize is cultivated from March to May depending on the rainfall distribution. Due to the availability of improved seeds, the maize yield has been steadily increasing after 1987/1988. The national area and yield of maize is estimated to be 870,166ha and $2159 \mathrm{~kg} / \mathrm{ha}$ respectively in 2007/08. The present rate of annual increase of temperature is $0.04^{\circ} \mathrm{C}$ in Nepal. Trends of temperature rise are not uniform throughout Nepal. An increase of annual temperature at Rampur during 1968-2008 was only $0.039^{\circ} \mathrm{C}$. However, at Rampur during the maize growing seasons, March/April - May, the trend of annual maximum temperature had not been changed, but during the month of June and July, the trend of increase of maximum temperature was $0.03^{\circ} \mathrm{C}$ to $0.04^{\circ} \mathrm{C} /$ year

Key words: Climate-change, global-warming, hill, mountain, Nepal, Tarai

\section{INTRODUCTION}

Ecologically, the country is divided into three regions running east to west: Mountain, Hills and Tarai (Plain). Based on the area, these regions constitute 35, 42 and 23 percent of the total land area, which is $147,181 \mathrm{sq}$. $\mathrm{km}$. Administratively the country is divided into 5 development regions and 75 districts. The area of development regions are shown in Fig.1.

Economic growth of the country has not improved over time to cope up with the population

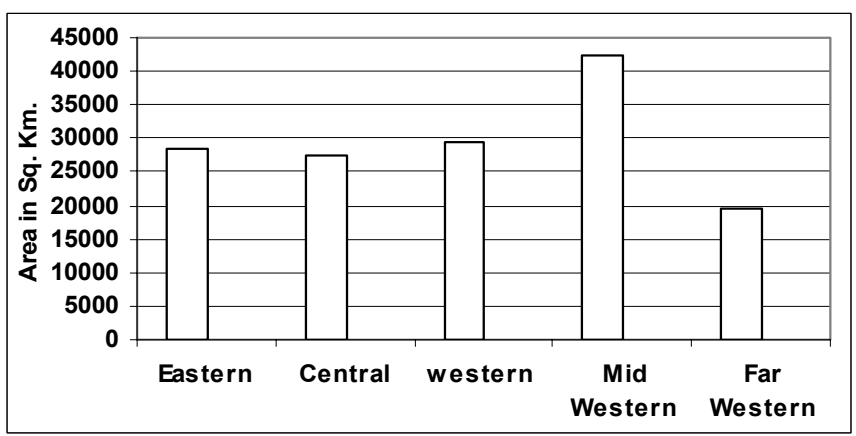
growth, which is 2.3 percent per annum. Around 68 percent of Nepal's population depends upon agriculture and contribution of this sector to the GDP is about 40 percent. Though priority is given to agriculture sector, the crop production in the country is not sufficient to meet the demand of the peoples.

Fig.1: Regional area of Nepal

According to the Population Census 2001, the number of agricultural holdings in the country is 3.2 million and total cultivated area is 23.21 million hectares. Starting from 1995, Nepal is implementing the twenty year long Agricultural Perspective Plan (APP) to overcome the

\footnotetext{
${ }^{1}$ Freelancer Consultant in Agro-meteorology, Email: drjanaklal@yahooo.com

${ }^{2}$ National Maize Research Project, Rampur, Email: nmrp@techminds.com.np
} 
problems of food insecurity and poverty. The population distribution along with the administrative region is shown in Fig. 2.

In Nepal maize is grown in the sub tropical to cool temperate climates. For higher yields, crop water requirement is $500-600 \mathrm{~mm}$ depending upon the climate and duration of the crop, there should be adequate water during the crop establishment period. Water deficit during the grain filling period results in reduced grain weight. However, during the maturity and harvesting period, rainfall has negative impact on maintaining grain quality.

Knowledge of genetic characteristics and particularly growth and development pattern of maize varieties is essential for meeting the combination of various climatic requirements for growth development and yield formation. It is known that the upper limit of crop production is set by the climatic condition specially temperature regimes and the genetic

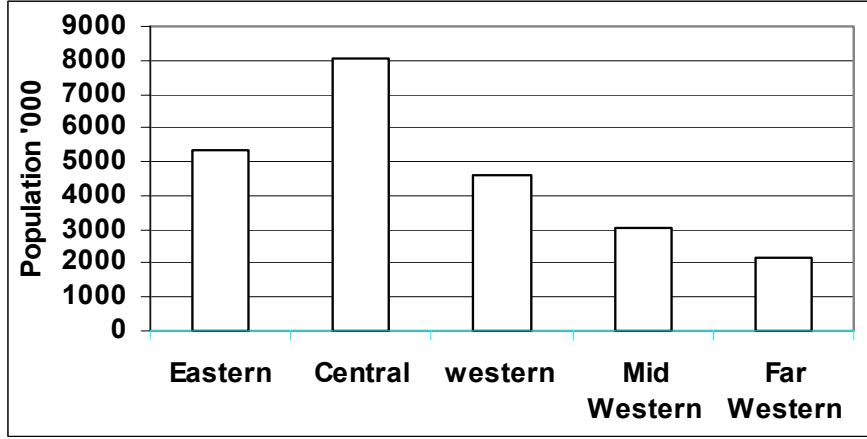

Fig.2: Population distribution in administrative region potential of the variety grown. The extent to which this limit can be reached will always depend on how finely the engineering aspects of water supply are in tune with the biological needs for water in crop production (FAO, 1979). The area under maize cultivation in different regions of Nepal is shown in Fig.3.

\section{DATA}

This study is based on data of thirty six years $(1970 / 71-2007 / 08)$. Climate data were provided by the Department of Hydrology and Meteorology (DHM, 1999a, 2001, 2002, 2005, 2007 and 2009). Source of the maize data is the then Department of Food and Agricultural Marketing Services (DFAMS, 1977), National Planning Commission (NPCS, 1994), Central Bureau of Statistics (CBS, 1999, 2003, 2006) and Ministry of Agriculture and Cooperatives (MoAC, 2002, 2004, 2005, 2006, 2007 and 2008).

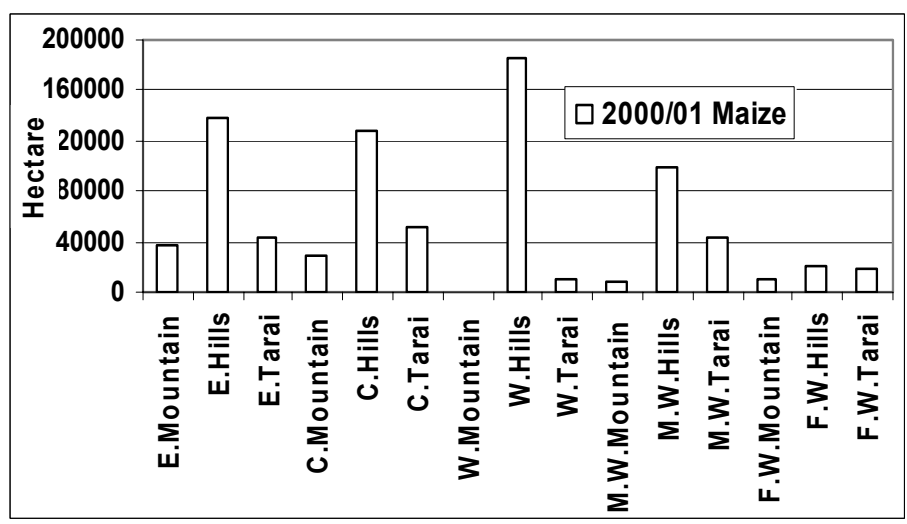

Fig. 3: Maize cultivation in the different regions in Nepal
Taking into consideration the growing season of summer maize, this study attempts to analyze relationship between rainfall and maize production for whole of Nepal and three ecological belts with a case study at the National Maize Research program in Rampur, which lies in inner Tarai of central Nepal. 


\section{ANALYSIS}

\section{NATIONAL LEVEL}

Maize is the second most important cereal crop in Nepal and is also staple food for Hills people. Area under this crop is approximately 870,166ha with an average productivity of $2159 \mathrm{~kg} / \mathrm{ha}$ in $2007 / 08$. About $70 \%$ maize area is in the Hills. Maize occupies $34 \%$ of total cultivated cereal crops and contributes $30 \%$ as a total edible food in Nepal. Maize is generally grown under rain-fed condition in Nepal. Maize is an important crop for making edible oil and is also significant source of bio-fuel production in the world. Maize is very sensitive to frost. The favorable condition of growing maize is light to medium textured, deep well drained soils free from water-logging. The cool temperature delays maturity in the crop. Cold stress occurs when temperature is below $10^{\circ} \mathrm{C}$ and development of plant growth ceases. Similarly, heat stress occurs when temperature is higher than $35^{\circ} \mathrm{C}$.

While observing the maize area in Nepal during 1970/71 to $2007 / 08$, the area was about 445,750 ha during $1970 / 71$ and the area has increased to 870,166 ha in $2007 / 08$. There is clear indication that the area under maize cultivation has increased nearly two folds in 2007 during the study period. The maize production was 833,318 MT in 1970/71 and now the production is $1,878,648$ MT in $2007 / 08$. The maize production during the study period of $1970 / 71-2007 / 08$ has more than doubled and that the increase in production was due to increase in area.

National Agriculture Research Council mentioned that performance in maize production in Nepal has not increased much even though use of improved seeds has increased substantially since 1972 . Although attempts on variety development were initiated since middle of sixties, the systematic development work began only after the National Maize Development Program established in 1972 at Rampur.

The seeds of new varieties have increased since then and now area under improved maize is 86\% (MOAC, 2008). There are altogether 23 varieties developed for different production environments in Nepal (NARC, 1997, 2005). Maize seeds are planted with $25 \mathrm{~cm}$ between plant to plant distance and $75 \mathrm{~cm}$ apart between rows to row. The ridges should be made very nicely and maintained to avoid water logging. In general, the first weeding is performed when the plants are 5-8 leaf stage and feeling up is done at the knee high stage.

The national maize area and production from 1970/71 to 2007/08 are shown in Fig.4. Initially during the first and half decade, the production had been decreasing and only after

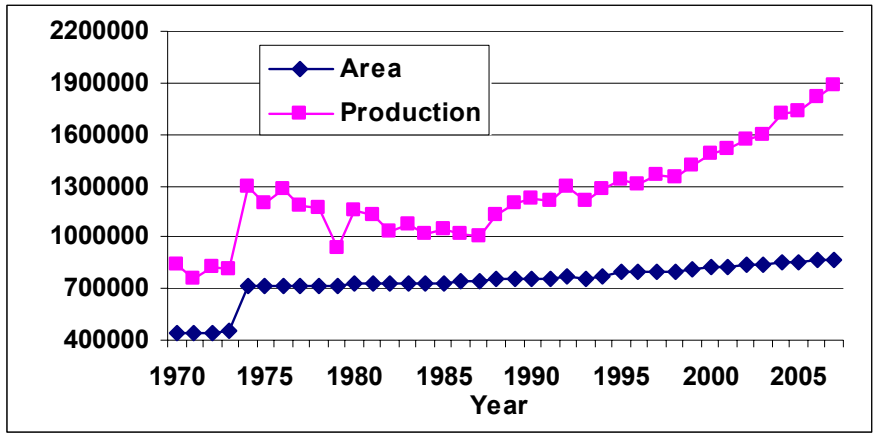

Fig. 4: National Maize area and Production 1986, the production had been steadily increasing trends. In the later part, the yield increased to more than 2 ton per hectare showing progress in maize yields, which is shown in Fig.4. It seemed that the increase in yield was mainly due to adoption of high yielding varieties. 


\section{ECOLOGICAL BELTS}

The Maize area and production in three ecological belts are as follows:

\section{Mountain}

In course of studying maize cultivation in the three ecological belts, the Mountain region showed least increment among the three belts The production of maize in the Mountain region increased from 77,800 MT to 183,253 MT during the last 36 years from 1970/71 to $2007 / 08$., But the yield has remained almost constant during the last 27 years and only after

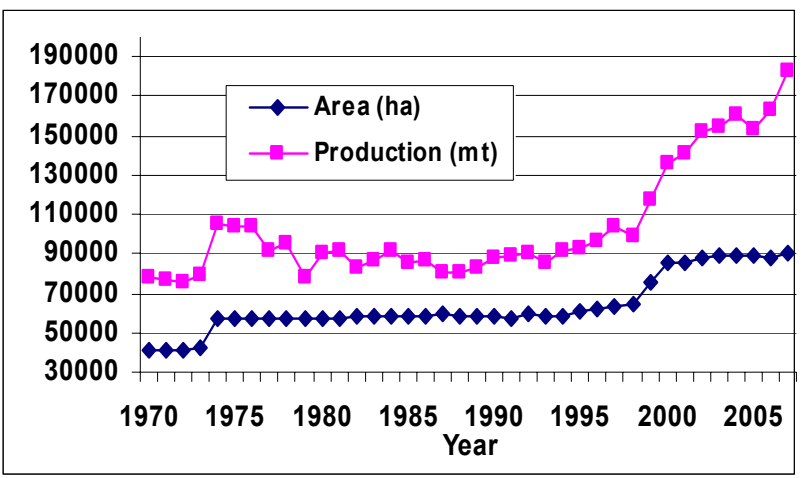

Fig.5: The maize area and production in Mountain 2000 the yield seemed to increase in mountain as shown in Fig.5. General maize plantation starts from March to April and it is totally dependent upon the rainfall. The average annual temperature during the growing season in Mountain was from $18^{\circ} \mathrm{C}$ to $21^{\circ} \mathrm{C}$. In fact, area under maize in mountain was $9.6 \%$ of the total maize area and contributed $10.3 \%$ of the total maize production in the country. In mountain regions, maize matured in around 180 days.

\section{Hills}

The maize growing season in the Hills Region is from March/April to July/August. Maize is planted in rain-fed condition in the Hills and depends upon the rainfall distribution. The land preparation starts with rainfall. Maize is generally planted from mid February to the end of April. Maize area is more in the Western Hills compared to the other Hills in Nepal as shown in Fig.6. The maturity period of maize in the hills ranged from 140 to 150 days.

Mean annual temperature during the growing period in the Hills ranged from $21^{\circ} \mathrm{C}$ to $27^{\circ} \mathrm{C}$. Hills regions showed nearly three fold increases in area during the period from 1970/71 to

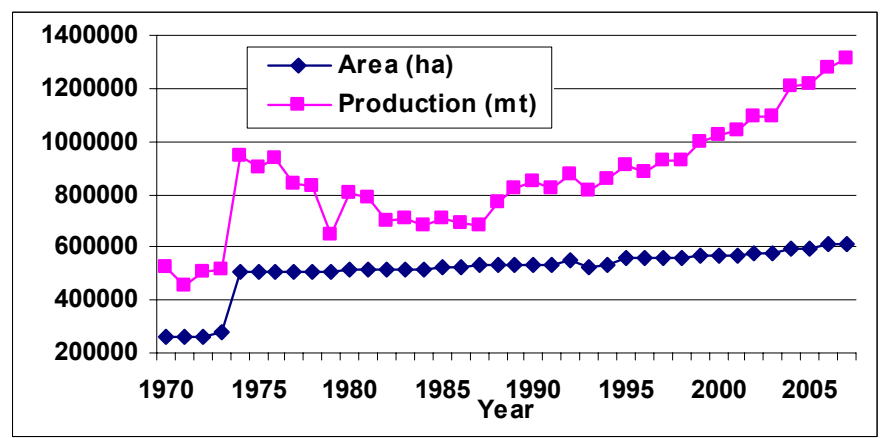

Fig. 6: The maize area and production in Hills 2007/08. The gap in area and production showed a progressive change after 1988 in the Hills (Fig.6). The production of maize in the Hills increased from 524,700 MT to 1312,254 MT during the study period. In fact Hills region has about $70.4 \%$ of the total maize area and contributes $69.7 \%$ of the total maize production in the country.

\section{Tarai}

Maize is grown during April- July in Tarai. During this period, about 500 to $800 \mathrm{~mm}$ rainfall occur in the Tarai. Annual mean temperature during the growing period of maize in Tarai is 
$21^{\circ} \mathrm{C}$ to $33^{\circ} \mathrm{C}$. In fact Tarai region has only $9.1 \%$ of the total maize area and contributes $20.4 \%$ of the total maize production in the country.

During the last 36 years period from 1970/71 to 2007/08 (Fig.7), the production of maize in the Tarai region increased from 230,700 MT to 383,141 MT. It is interesting to note that the maize yield in Tarai was initially low. In Tarai, area under maize increased by $60 \%$ and its yield increased only $71 \%$.

Maize is planted in all three seasons (summer, winter and spring) in the Tarai Region. The planting of summer maize starts from April to May and harvests on August to September. The growing season of winter maize covers from November/ December to March/ April. Similarly,

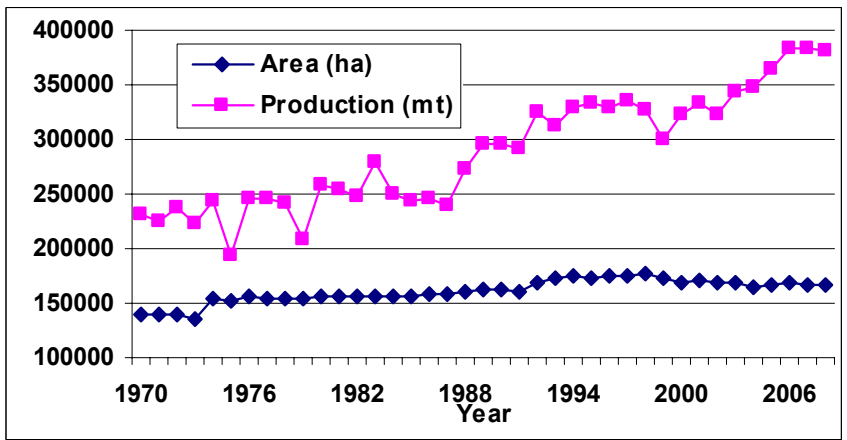

Fig. 7: The maize area and production in Tarai

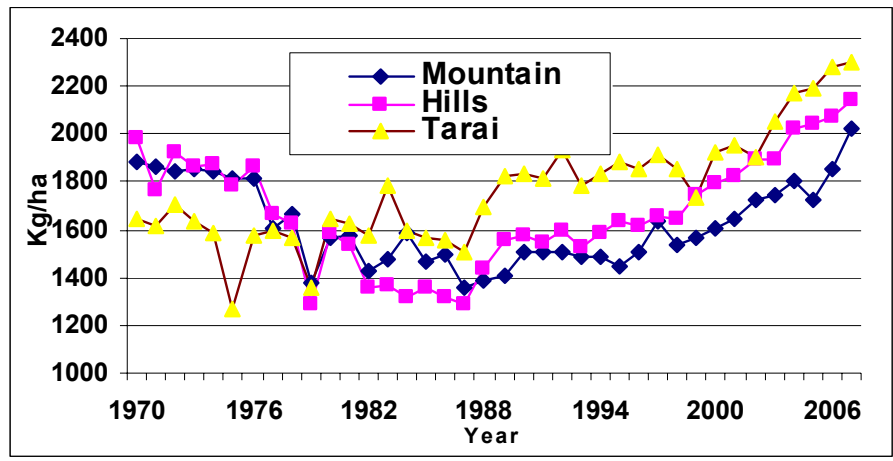
the growing season of spring maize is in March/April and harvests on June to early July. For the summer and winter crops, farmers prefer to grow long duration varieties, where as for the spring maize short duration varieties are preferred. Winter and spring maize is planted, wherever the irrigation facilities are available.

After the introduction of high yielding varieties, the yield increased in Tarai comparatively more than those of the Hills and Mountain. The yield at three ecological belts are presented in Fig.8, which shows that the yield is higher in the Tarai than in the Hills and the Mountain region.

Fig. 8: The maize yield at three ecological belts

\section{A CASE STUDY: NATIONAL MAIZE RESEARCH CENTRE, RAMPUR}

The simplified mathematical model known as growth indices developed by Fitzpatrick and Nix (1970) was calibrated in the Nepalese environment by Nayava(1981) and is presented with data from the meteorological station, Rampur, 256m, a district in Central Nepal (Fig.9a and Fig.9b).

The growth Indices (G.I.) considers light (LI), thermal (TI) and moisture regimes (MI) into a linear function with a scale ranging from zero to unity. In this analysis, growth indices (G.I.) has been defined as most favorable G.I. (higher than 0.8 ), fairly favorable G.I. (0.4 to 0.8 ) and least favorable G.I. (less than 0.4 ) are noted. The most favorable climatic condition for cultivation where all environmental indices such as light, thermal and moisture are nonlimiting factor for growth, in other words, the index should be higher than 0.8 . As a matter of fact, the energy and moisture balance are very necessary for crop under study. The Fig.9a indicate that only one tropical species (TS) can be grown under optimum condition during 
the week 23 to 42 (June 4 - 10 to October 16 - 22) as rain-fed condition in summer season. Fig. $10 \mathrm{~b}$ show that the three crops (two tropical species during the week 12 to 42 (March 19 -

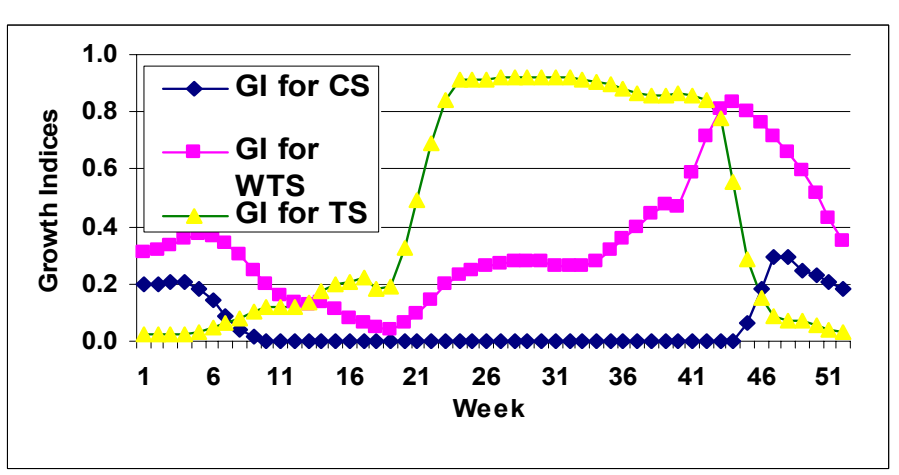
25 to October 16 - October 22) and one warm temperate species (WTS) as wheat during the week 43 to 13 (October 23 October 29 to March 26 April 1) can be easily managed with proper irrigation facilities. Cold temperate species (CTS) can not be grown in rainfed as well as irrigated condition.

Fig. 9a: Growth Indices at Rampur in rain-fed conditions

Thus, only one crop as tropical species can be cultivated in the rain-fed condition for optimum yield during the summer monsoon as shown in Fig.9a. The second and third crop can be managed only by irrigation application as described earlier and is shown in Fig. 9b. It is necessary to have short period of data such as weekly or decade to study the relation between crop and climate data, because normal (Long Term Average) and monthly data may

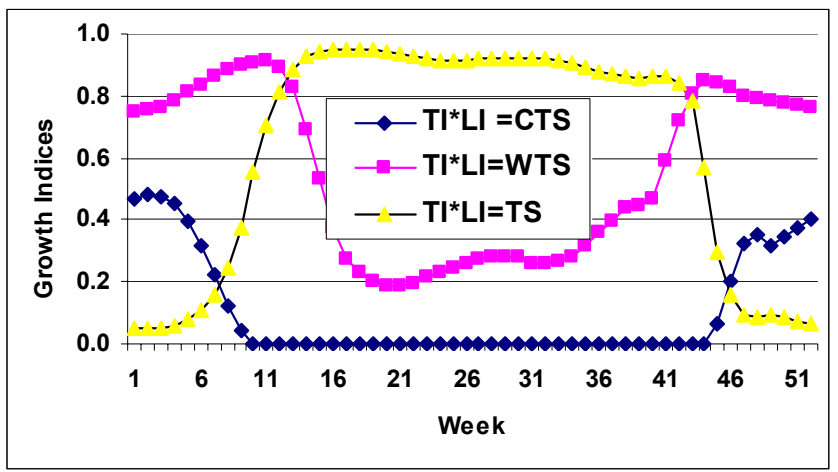
be equal, but the rainfall may had fall within one or two days at the end of the month and where a long intervals of three to four week dry period may have wilted the crop. On the other hand, a short period of squall or hailstorm will just damaged the whole crop in the ground. FAO suggests 10 days period would be just right for crop weather analysis.

Fig. 9b: Growth Indices at Rampur in Irrigated conditions

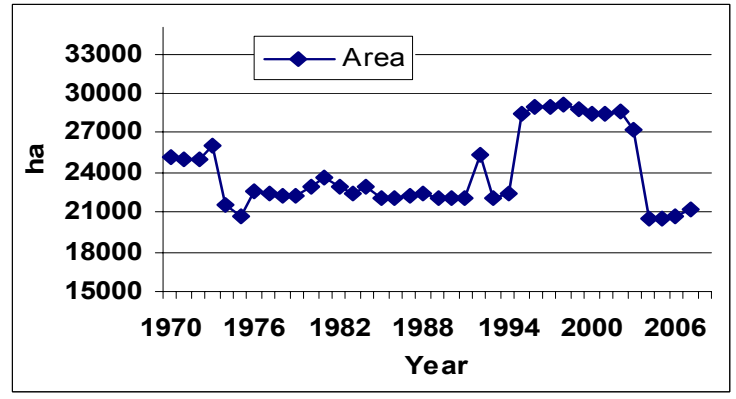

It is interesting to note that the maize yield in Tarai, Hills and Mountain justify the crop weather model patterns as described earlier. According to crop weather model, the Tarai is most favorable, the Hills and Mountain are relatively less favorable. The results were tallied by yield pattern in different ecological belt as discussed earlier.

Fig. 10: Maize area in Chitwan

In Nepal adaptation of modern farming technique and varietal improvement Maize started from Rampur Agricultural farm in Chitwan district during the early 1970's. A long time series of area, yield and production data of maize are only available at district level in Nepal. 
Rampur comes under Chitwan district and therefore, Chitwan district data has been analyzed and presented here. The area of maize remained almost constant throughout 1974 to 1994 ,

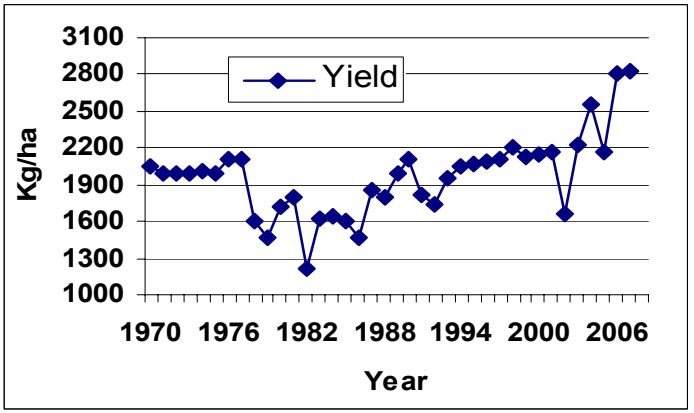
but 1995 to 2003 showed much higher in area and a later four years showed less (Fig.10). Why it was so, the reasonable explanation was not available. Similarly the yield showed decreasing tendency up to 1987 and later showed the increased trend as shown in Fig.11. The recent increase of increase of yield may not be only due to introduction of high yielding seeds, but may have been due to climate change factor. Discussions are very much required to draw any conclusion.

Fig. 11: Maize yield in Chitwan

This increase in maize yield is due to use of high yielding seeds which have been confirmed

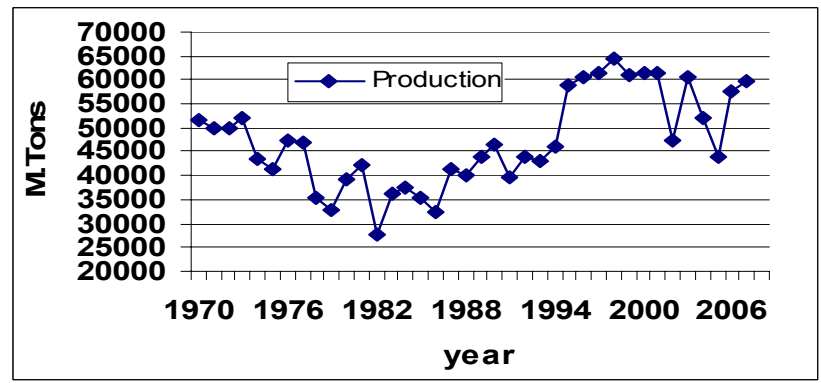
by personal discussion with the concerned authorities. While looking at the Fig.10, the cultivated area seemed just jumped during 1990's and later lower than the 1980's and therefore the concerned authorities should take note of this matter in future estimation. The production of maize in Chitwan district is shown in Fig.12

Fig. 12: Production of maize at Chitwan district

It is interesting to note that the shortfall of production of maize was noted in 1974, 1975, 1978, 1979, 1982, 1985, 1986, 1988, 1991, 1993, 1999, 2002 and 2005. This shortfall is as compared to the preceding year. The 13 years had shortfall of production out of thirty eight years. The decade rainfall and number of rainy days during that decade in the February to May during those years was presented in Table 1 . The table indicates that the rainfall during

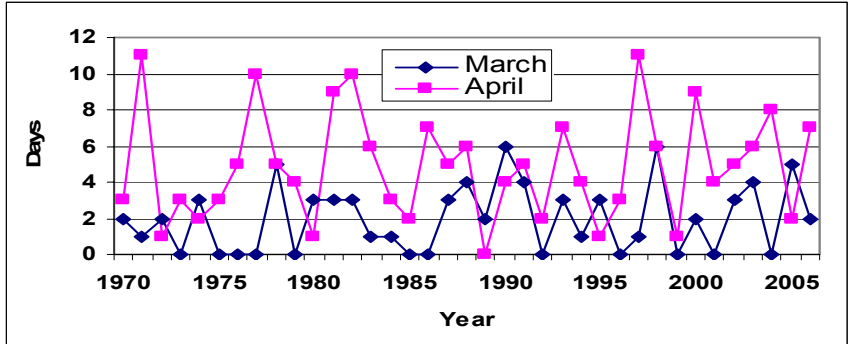
the emergence period in all those years was very poor and therefore production may have been affected. When one relates the rainfall data with crops, the rainfall characteristics such as depth, intensity and distribution in time and space are all important factors.

Fig. 13: Number of days of rainfall during March and April at Rampur

The water requirement of crops at the different stages, effective rainfall, water holding capacity of the soil and the crop coefficient are all required. Number of days of rainfall during those months of March and April and the amount of rainfall during those months are also presented in Fig.13 and 14. Similarly, the amount of rainfall during the months of May, 
June and July are also presented in Fig.15. If maize planted in May and June, this shows that

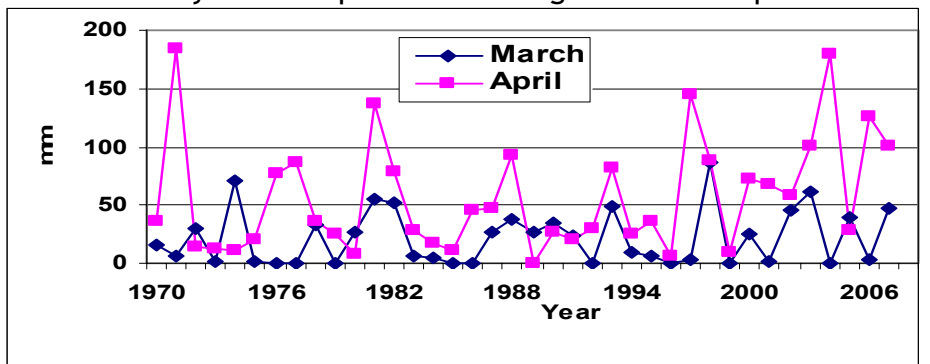

Fig. 14: Amount of rainfall during March and April at Rampur

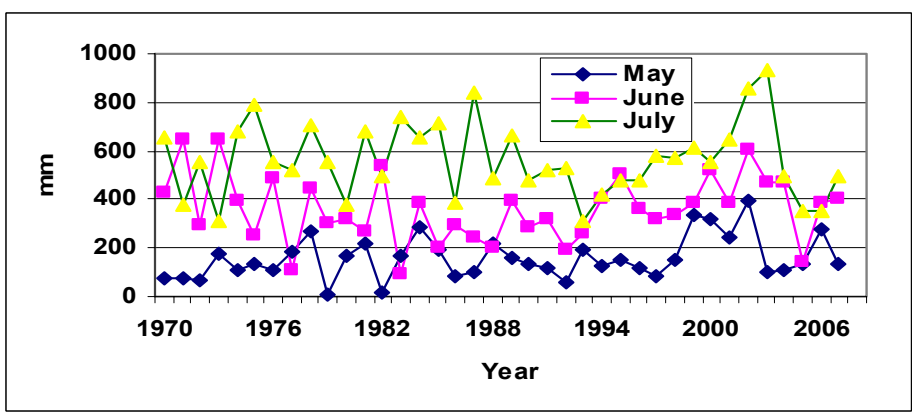
the amount of rainfall and the soil moisture will be quite enough for emergence and vegetative period of maize, On the contrary, the rainfall in March and April is erratic and may not be sure to have enough soil moisture for emergence period.

Fig. 15: Amount of rainfall during June, July and August at Rampur

Table 1: Decade Rainfall and rainy days $>1.0 \mathrm{~mm}$ in Rampur at the lower production year of maize

\begin{tabular}{|c|c|c|c|c|c|c|c|c|c|c|c|c|}
\hline & \multicolumn{3}{|c|}{ February } & \multicolumn{3}{|c|}{ March } & \multicolumn{3}{|c|}{ April } & \multicolumn{3}{|c|}{ May } \\
\hline rear & Decade & Decade & Decade & Decade & Decade & Decade & Decade & Decade & Decade & Decade & Decade & Decade \\
\hline & 1 & 2 & 3 & 1 & 2 & 3 & 1 & 2 & 3 & 1 & 2 & 3 \\
\hline 974 & $0.0 / 0$ & $0.6 / 0$ & $0.0 / 0$ & $0.0 / 0$ & $0.0 / 0$ & $71.3 / 3$ & $3.8 / 1$ & $0.0 / 0$ & $8.0 / 1$ & $21.1 / 3$ & $45.1 / 7$ & $44.0 / 2$ \\
\hline 975 & $10.0 / 3$ & $4.3 / 1$ & $0.0 / 0$ & $0.3 / 0$ & $0.5 / 0$ & $6.4 / 1$ & $0.0 / 0$ & $0.0 / 0$ & $21.1 / 5$ & $0.0 / 0$ & $65.8 / 5$ & $66.3 / 5$ \\
\hline 978 & $16.0 / 2$ & $10.2 / 1$ & $0.0 / 0$ & $1.0 / 0$ & $32.8 / 4$ & $0.0 / 0$ & $0.0 / 0$ & 29.5/4 & $6.9 / 1$ & $41.5 / 5$ & $163.2 / 7$ & $62.2 / 4$ \\
\hline 979 & 7.7/1 & $7.0 / 1$ & $0.0 / 0$ & $0.5 / 0$ & $0.2 / 0$ & $0.0 / 0$ & $1.5 / 1$ & $12.4 / 2$ & $0.6 / 1$ & $0.0 / 0$ & $1.7 / 1$ & $6.8 / 1$ \\
\hline 1982 & $7.8 / 2$ & $0.5 / 0$ & $0.0 / 0$ & $51.0 / 3$ & $0.0 / 0$ & $0.9 / 0$ & $3.4 / 1$ & $47.1 / 5$ & $28.7 / 4$ & $0.0 / 0$ & $15.8 / 2$ & $5.2 / 1$ \\
\hline 985 & $11.1 / 1$ & $0.0 / 0$ & $0.0 / 0$ & $0.0 / 0$ & $0.0 / 0$ & $0.0 / 0$ & $5.2 / 1$ & $0.0 / 0$ & $6.2 / 1$ & $21.5 / 4$ & $89.9 / 6$ & $83.0 / 6$ \\
\hline 1986 & $2.8 / 1$ & $17.4 / 2$ & $0.0 / 0$ & $0.0 / 0$ & $0.0 / 0$ & $0.0 / 0$ & $1.8 / 1$ & $16.7 / 1$ & $26.8 / 5$ & $6.9 / 2$ & $50.7 / 6$ & $27.8 / 2$ \\
\hline 988 & $0.0 / 0$ & $0.8 / 0$ & $1.9 / 1$ & $12.2 / 1$ & $26.0 / 3$ & $0.0 / 0$ & $0.0 / 0$ & $53.7 / 3$ & $38.5 / 3$ & $16.9 / 3$ & $69.9 / 5$ & $133.6 / 7$ \\
\hline 991 & $0.0 / 0$ & $0.0 / 0$ & $8.4 / 1$ & $12.2 / 2$ & $0.6 / 0$ & $10.9 / 2$ & $11.9 / 2$ & $0.0 / 0$ & $9.1 / 3$ & $11.3 / 3$ & $38.3 / 3$ & $64.3 / 8$ \\
\hline 1993 & $0.0 / 0$ & $9.1 / 1$ & $0.0 / 0$ & $0.0 / 0$ & $0.0 / 0$ & $49.4 / 3$ & $0.0 / 0$ & $55.4 / 3$ & $27.1 / 4$ & $48.8 / 2$ & $73.5 / 6$ & $63.2 / 4$ \\
\hline 1998 & $0.0 / 0$ & $0.0 / 0$ & $0.0 / 0$ & $0.0 / 0$ & $0.0 / 0$ & $0.0 / 0$ & $10.1 / 1$ & $0.0 / 0$ & $9.1 / 3$ & $143.5 / 7$ & $2.0 / 1$ & $4.6 / 1$ \\
\hline 2002 & $0.0 / 0$ & $13.2 / 1$ & $15.1 / 2$ & $11.2 / 1$ & $0.0 / 0$ & $34.4 / 2$ & $10.5 / 1$ & $0.0 / 0$ & $40.0 / 4$ & $104.4 / 5$ & $168.3 / 7$ & $119.2 / 5$ \\
\hline 2004 & $0.0 / 0$ & $0.0 / 0$ & $0.0 / 0$ & $0.0 / 0$ & $0.0 / 0$ & $0.0 / 0$ & $90.0 / 4$ & $0.0 / 0$ & $90.2 / 4$ & $4.1 / 1$ & $22.6 / 2$ & $84.7 / 7$ \\
\hline 2005 & $2.2 / 1$ & $1.4 / 1$ & $1.2 / 1$ & $0.0 / 0$ & $35.6 / 3$ & $3.3 / 2$ & $0.0 / 0$ & $0.0 / 0$ & $28.7 / 2$ & $36.1 / 2$ & $83.6 / 5$ & $13.8 / 3$ \\
\hline
\end{tabular}

\section{CLIMATE CHANGE AND THEIR EFFECTS ON MAIZE}

In the present scenarios of climate change, the impact on agriculture has to be explored and this is very enormous and complex task, but the country should immediately start planning and take action, before it is too late. The mean annual temperature trend at Rampur during 1968 to 2008 is shown in Fig. 16. It showed that the increase of temperature seemed to be more in the recent decade than the former decade and the trend was $0.039^{\circ} \mathrm{C}$ per year. 
The maximum temperature trend at Rampur during the maize growing season from March to July was also analyzed as shown in Fig.17- 21. The trend of maximum temperature during April and May showed negative trend (Fig.18 and 19) and the month of June and July showed the positive trend as shown in Fig.17 and 18.

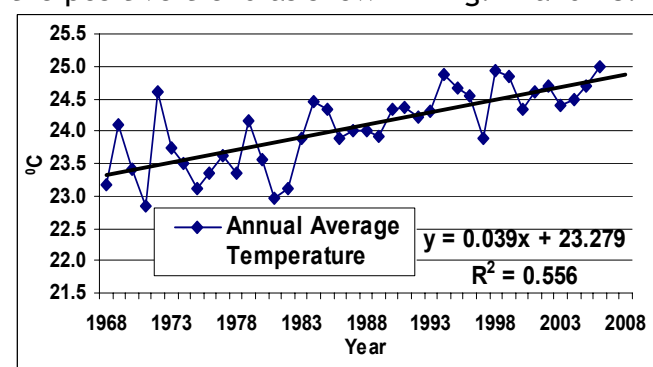

Fig. 16: Trend of annual average temperature

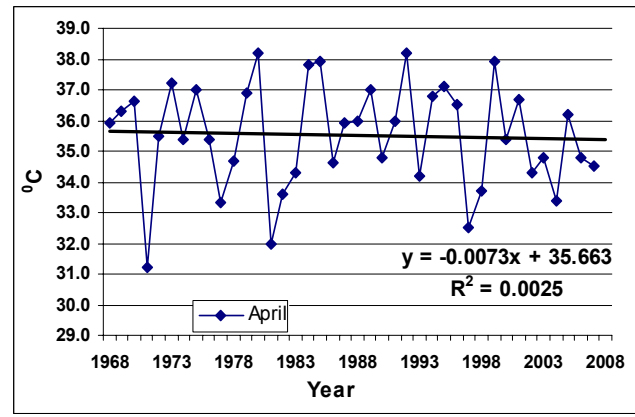

Fig. 18: Trend of max. temperature during April

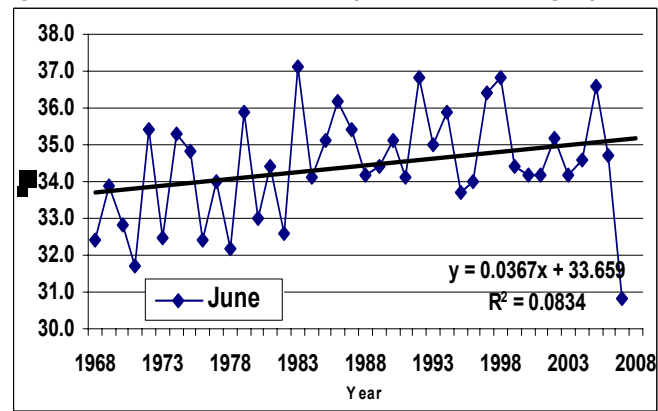

Fig. 20: Trend of max. temperature during June

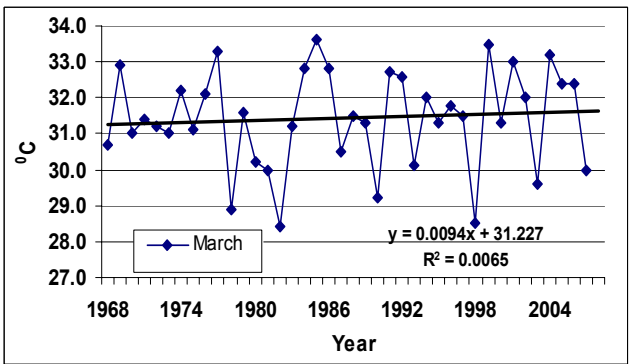

Fig. 17: Trend of maximum temperature during March

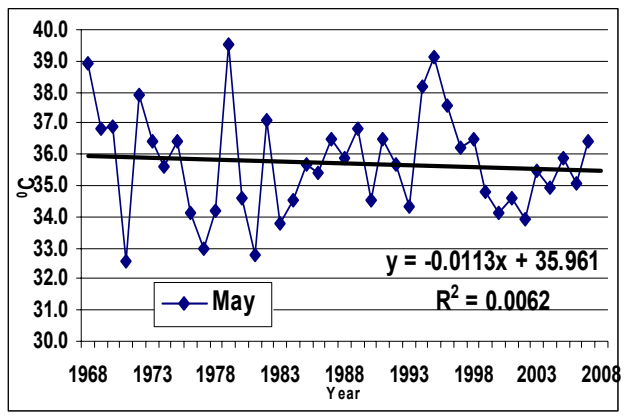

Fig. 19: Trend of max. temperature during May

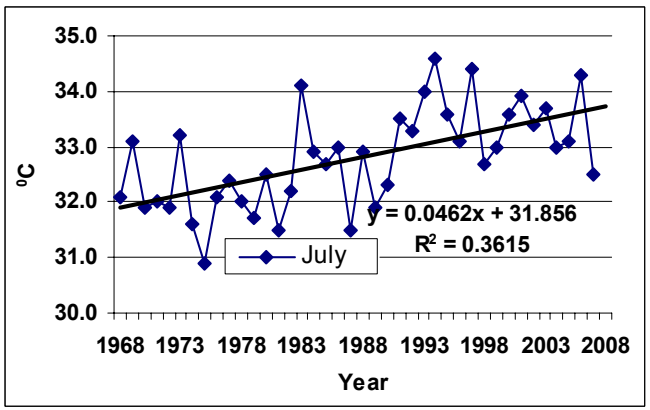

Fig. 21: Trend of max. temperature during July

Recently the effect of climate change to agriculture in Nepal was also studied by different researchers. The APN report shows, when the temperature rises up to $1^{\circ} \mathrm{C}$, there is a positive role in percentage change in maize yield in all the agro-ecological zones. When the temperature rises up to $2^{\circ} \mathrm{C}$ and at the same time carbon dioxide is doubled, the yield will decrease in Tarai, Hills will not be much affected. On the contrary, Mountain environment will have better yield if the carbon dioxide is doubled and temperature rises up to $4^{0} \mathrm{C}$, the maize yield in Tarai will suffer $25 \%$ lesser than the present yield. Therefore the study of present variation of climatic parameters such as rainfall and temperature in the crop yield should be regularly studied and discussed. 


\section{PROBLEMS ENCOUNTERED}

- Gray Leaf Spot is a great threat

- Gray leaf spot, a new disease of maize is a great threat in the mid hills of Nepal. Local varieties are more susceptible to this disease than improved varieties. Improved varieties such as Manakamana-3, Shitala, Deuti, Ganesh -1 and Ganesh -2 are less susceptible and thus these varieties need to be promoted in eastern and central hills of Nepal.

- Post harvest losses (storage)

- Post harvest losses due to diseases and storage pests should be minimized. Grain weevils are the major storage pest of maize in Nepal.

- Climate Change (Drought)

- Drought is prolonging year after year in Nepal. Development of drought tolerant varieties is the answer to the drought problem. Adjustment of planting season could help to escape the critical stage of crops to escape from the drought.

- One of the drought tolerant characters in a variety is having less anthesis and silking

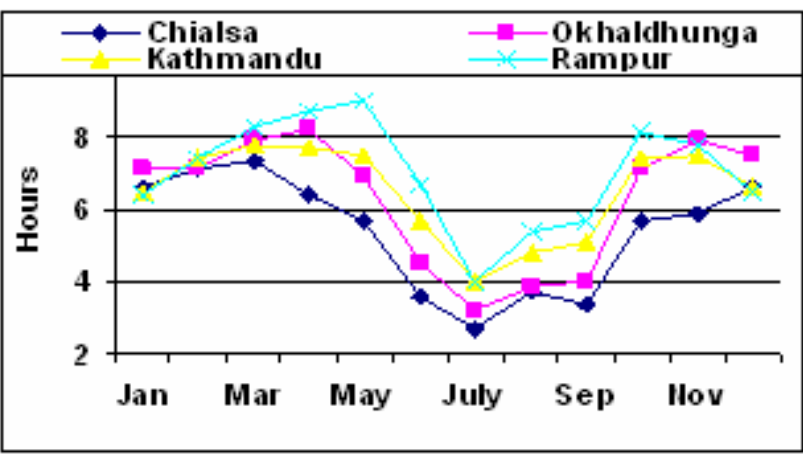
interval (ASI) in maize. Shorter ASI will escape drought in maize cultivation. Varieties with long ASI are more vulnerable to drought. In the context of climate change, development of drought tolerant varieties is one of the options to overcome the drought and answer to the problem of climate change.

Fig. 22: Sun shine hours at the different places

\section{DISCUSSION}

- Despite the importance of maize, the yield has not been increased to satisfactory level. The production seemed to increase due to more land brought under cultivation he low yield of maize may be due to the following reasons.

- It is noted earlier that out of 38 years, 13 years had poor rainfall during the maize emergence period that affected maize production in those years.

- The second possible factor may be due to lower sunlight during the grain formation stage of maize and thereby, lower photosynthetic rate. Sunshine hours at Rampur, Kathmandu, Okhaldhunga, and Chialsa had low during July and August. During those months there is highest rainfall in Nepal. The long term average sunshine hours at Rampur, 256m; Kathmandu, 1336m, Okhaldhunga, 1720m and Chialsa, 2770 of Nepal at the different elevations are presented in Fig.22.

- During the maturity period, the high rainfall and high humidity caused maize disease such as BLSP and Turccicum blight resulting low maize production.

- Drought period is prolonging year after year in Nepal and same as the onset of monsoon. Planting of maize in rain-fed conditions depend upon the rainfall, one need to rethink on maize planting based on rainfall pattern. May to June planting and October/ November harvesting would be suitable for maize cultivation in Nepal. For this, experiment of maize planting on these months should be conducted. 


\section{RECOMMENDATION AND CONCLUSION}

- The study of maize yield and production with relation to pre-monsoon rainfall (MarchMay) for the 1971-2008, through crude analysis, showed that maize yield in Chitwan was badly affected in thirteen years particularly in the years, 1974, 1975, 1978, 1979, 1982, 1985, 1986, 1989, 1991, 1993, 1999, 2002, and 2005. During those years the premonsoon rainfall was much below lower than normal rainfall. Therefore the impact of rainfall on maize yield and production is quite evident. Maize planting in the Chitwan should be adjusted according to the change in rainfall pattern in the recent decades.

- According to the crop weather model show in Fig.9a, the most favourable condition of tropical species at rain-fed condition lies in June to October and therefore the maize should be planted during that period.

- The present system of monitoring and evaluation of crop from Ministry of Agriculture and Cooperatives should be strengthened by updating the cultivated areas.

\section{REFERENCES}

DFAMS, 1977. Agricultural Statistics of Nepal, 1977, Department of Food and Agricultural Marketing Services (DFAMS), Ministry of Agriculture (MoA), HMG of Nepal, Kathmandu.

CBS, 1999. Agricultural Statistics of Nepal, CBS, NPC, HMG of Nepal, Kathmandu.

CBS, 2003. Agricultural Statistics of Nepal, CBS, NPC, HMG of Nepal, Kathmandu.

CBS, 2006. Monograph, Agriculture Census, Nepal, 2001/2002, CBS, NPC, Government of Nepal, Kathmandu.

DHM, 1997. Climatological Records of Nepal (1991-1994), DHM, Kathmandu, Nepal.

DHM, 1999a. Daily precipitation records of gandaki and narayani Zones through 1966, Department of Hydrology and Meteorology (DHM) Kathmandu, Nepal.

DHM, 2001. Daily Precipitation Records of Nepal, 1997-1998, DHM, Kathmandu, Nepal.

DHM, 2002. Climatological Records of Nepal (1999-2000), DHM, Kathmandu, Nepal.

DHM, 2005. Climatological Records of Nepal (2001-2003), DHM, Kathmandu, Nepal.

DHM, 2007. Climatological Records of Nepal (2004-2005), DHM, Kathmandu, Nepal.

DHM, 2009. Climatological Records of Nepal (2006-2007), DHM, Kathmandu, Nepal

FAO, 1979. Yield response to water, FAO Irrigation and Drainage Paper 33, Rome

Fitzpatrick, E. A. and H. A. Nix. The climatic factor in Australian grassland ecology. In. R. M. Moore (ed.), Australian Grassland. Canberra: The Australian National University Press, pp.3-26.

MoAC, 2002. Statistical Information on Nepalese Agriculture, 2001/2002. Ministry of Agriculture and Coperatives, Kathmandu.

MoAC, 2004. Statistical Information on Nepalese Agriculture, 2002/2003. Ministry of Agriculture and Coperatives, Kathmandu.

MoAC, 2004. Statistical Information on Nepalese Agriculture, 2003/2004. Ministry of Agriculture and Coperatives, Kathmandu.

MoAC, 2005. Statistical Information on Nepalese Agriculture, 2004/2005. Ministry of Agriculture and Coperatives, Kathmandu.

MoAC, 2006. Statistical Information on Nepalese Agriculture, 2005/2006. Ministry of Agriculture and Coperatives, Kathmandu.

MoAC, 2007. Statistical Information on Nepalese Agriculture, 2006/2007. Ministry of Agriculture and Coperatives, Kathmandu.

MoAC, 2008. Statistical Information on Nepalese Agriculture, 2007/2008. Ministry of Agriculture and Coperatives, Kathmandu.

NARC, 2005. Released and registered crop varieties in Nepal. Nepal Agricultural Research Council, Kathmandu.

NARC, 1997. 25 Years of Maize Research in Nepal (1972-1997). National Maize research Program, Nepal

Nayava, J. L., 1981. Climates of Nepal and their implications to agricultural development. Ph.D thesis submitted to the Australian National University, Canberra, Australia.

NPCS, 1994. Agricultural statistics of Nepal revised cropped area series, 1974/75- 1991/92. National Planning Commission Secretariate, Singh Durbar, Kathmandu.

\section{ACKNOWLEDGEMENT}

The authors wish to thank Mr. Rabi Singh, former Deputy Director General, Central Bureau of Statistics, for his suggestions and comments on this paper. 